6. Угода між Кабінетом Міністрів України і Урядом Королівства Данія про реадмісію осіб. Учинена в м. Копенгаген 16.03.2007 p. URL: https://zakon.rada.gov.ua/laws/show/208_017\#Text (дата звернення: 20.12.2021).

7. Угода між Кабінетом Міністрів України та Урядом Ісландії про реадмісію осіб. Вчинено в м. Нью-Йорк 25.09.2013 p. URL: https://zakon.rada.gov.ua/laws/show/352_004\#Text (дата звернення: 20.12.2021).

8. Угода про реадмісію осіб між Кабінетом Міністрів України та Урядом Королівства Норвегія. Вчинено в м. Осло 13.02.2008 p. URL: https://zakon.rada.gov.ua/laws/show/578_019\#Text (дата звернення: 20.12.2021).

9. Угода між Кабінетом Міністрів України та Швейцарською Федеральною Радою про реадмісію осіб, які перебувають на територіях ïх держав нелегально. Вчинено у м. Києві 11.07.2003 p. URL: https://zakon.rada.gov.ua/laws/show/756_022\#Text (дата звернення: 20.12.2021).

10. Угода між Україною та Швейцарською Конфедерацією про реадмісію осіб. Учинено в м. Київ 07.06.2017 p. URL: https://zakon.rada.gov.ua/laws/show/756_001-17\#Text (дата звернення: 20.12.2021).

\title{
DOI https://doi.org/10.30525/978-9934-26-179-4-56
}

\section{МІЖНАРОДНО-ПРАВОВА РЕГЛАМЕНТАЦІЯ ПРАВ КОРІННИХ НАРОДІВ}

\author{
Реньов С. В. \\ кандидат юридичних наук, \\ доиент кафедри міжнародного і європейського права \\ Харківський національний університет імені В. Н. Каразіна \\ м. Харків, Україна
}

Питання міжнародної регламентації прав корінних народів набуло особливого значення для України після окупації Автономної Республіки Крим. I не втрачає своєї актуальності вже восьмий рік зокрема, у минулому місяці у Сімферополі затримали 31 активіста, що в черговий раз обурило усю міжнародну спільноту. 
«Масові затримання Росією кримських татар повинні припинитись. Велика Британія закликає Росію припинити свої неприйнятні спроби залякати кримськотатарську спільноту», - наголосили у посольстві Великої Британії в Україні [1].

Ще у 2014 році Верховна Рада України прийняла постанову, якою визнала кримських татар корінним народом. А у цьому році набув чинності Закон України «Про корінні народи України», відповідно до якого корінними народами України, які сформувались на території Кримського півострову, є кримські татари, караїми та кримчаки [2]. Все це зумовлює необхідність аналізу міжнародно-правової регламентації прав корінних народів для подальшого ефективного використання інструментів захисту даної категорії осіб в Україні.

Декларація про права корінних народів була прийнята Генеральною асамблеєю ООН у 2007 році. Ї̈̈ підтримали 143 країни з 192, а Україна утрималася. Таку пересторогу можна пояснити проголошеним у Декларації правом корінних народів на самовизначення та на автономію або самоуправління у питаннях, які належать до їхніх внутрішніх і місцевих справ. Однак 22 травня 2014 року, в рамках Постійного Форуму ООН 3 питань корінних народів, українська делегація зробила офіційну заяву, відповідно до якої просила вважати Україну державою, що офіційно підтримала Декларацію про права корінних народів.

Тим паче, у ч. 1 ст. 46 Декларації ООН про права корінних народів вказано: «Ніщо в цій Декларації не може бути витлумачене як таке, що санкціонує або заохочує до будь-якої дії, яка вела б до роз'єднання або до часткового чи повного порушення територіальної цілісності та політичної єдності суверенних і незалежних держав» [3].

Окремої уваги заслуговує й перший у цьому питанні міжнародноправовий акт, який був прийнятий Міжнародною організацією праці у 1957 році, а саме Конвенція № 107 про захист і інтеграцію корінного та іншого населення, що веде племінний i напівплемінний спосіб життя, у незалежних державах. Саме на іï основі у 1989 році була прийнята Конвенція Міжнародної організації праці № 169 «Про корінні народи, які ведуть племінний спосіб життя в незалежних країнах».

Згадана Конвенція має дуже важливе значення у контексті визнання наявності у корінних народів колективних прав, особливих прав на землі та території, власних правових систем та низки обов'язків держави відносно корінних народів, а тому могла би підсилити нашу національну політику у сфері захисту корінних народів. Однак цей договір набув реальної значущості тільки на регіональному рівні - a 218 
саме у державах Латинської Америки [4, с. 8]. Україна, як і більшість європейських держав, Конвенцію МОП № 169 поки не ратифікувала, хоча цьогорічне приєднання до Конвенції Німеччини може стати відчутним поштовхом й для інших країн нашого континенту.

Також доцільно перелічити прийняті Радою Європи Рамкову конвенцію про захист національних меншин 1995 року та Європейську хартію регіональних мов національних меншин 1992 року, оскільки вони суттєво підсилюють міжнародно-правовий інструментарій захисту прав національно-етнічних спільнот.

Повертаючись до питання захисту прав корінних народів в Україні, Свропейський парламент у своїй резолюції від 11 лютого 2021 року закликав нашу державу внести зміни до Конституції щодо визнання національно-територіальної автономії кримськотатарського народу в складі України [5].

У цьому контексті можна навести думку Хьорста Ханнума, що право на автономію - це право меншин та спільнот корінних народів на здійснення виразного внутрішнього самовизначення та контролю над своїми справами у такий спосіб, який не перешкоджає вищому суверенітетові держави [6, с. 473]. Противники ідеї національнотериторіальної якраз і вважають, що іiі проголошення може стати прикладом для інших районів компактного мешкання національних меншин в Україні. Найчастіше згадується угорська етнічна громада на Закарпатті.

Цього року Ужгород і Берегове відвідав Верховний комісар ОБСЄ у справах національних меншин Кайрат Абдрахманов, що відображено у його звіті [7]. Верховний комісар зосереджує свою увагу саме на тих питаннях, які можуть вплинути на безпеку в регіоні ОБСЄ, тож цей візит є доволі показовим.

Таким чином, якщо підтримка Україною Декларації ООН про права корінних народів 2007 року отримала загальну схвальну оцінку, то питання національно-територіальної автономії потребує подальшого вивчення, адже право на створення адміністративно-територіальних одиниць традиційно визнається за тими національно-етнічними спільнотами, які становлять більшість населення певної території. Доречно навести приклад Гренландії, автономії у складі Королівства Данія, що $є$ територіальною автономією корінного народу інуїтів (90\% місцевого населення). Вказаний приклад суттєво контрастує 3 кількісними показниками кримських татар, кримчаків і караїмів на території Кримського півострову. 


\section{Література:}

1. Russia's continued mass detentions of Crimean Tatars must stop. Official Twitter account of the British Embassy Kyiv. URL: https://twitter.com/UKinUkraine/status/1463485513306939400 (date of request: 01.12 .2021$)$.

2. Про корінні народи України: Закон України від 01.07.2021 р. № 1616-IX. URL: https://zakon.rada.gov.ua/laws/show/1616-20\#Text (дата звернення: 20.12.2021).

3. United Nations Declaration on the Rights of Indigenous Peoples № 61/295. Resolution adopted by the General Assembly on 13 September 2007. The United Nations. URL: https://undocs.org/A/RES/61/295 (date of request: 20.12.2021).

4. Приходько А. В. Стандарти ООН стосовно прав корінних народів: автореф. дис. канд. юрид. наук: 12.00.11. Одеса, 2017. 20 с.

5. European Parliament resolution of 11 February 2021 on the implementation of the EU Association Agreement with Ukraine. European Parliament. URL: https://www.europarl.europa.eu/doceo/document/ TA-9-2021-0050_EN.html (date of request: 20.12.2021).

6. Hurst Hannum. Autonomy, sovereignty, and self-determination: the accommodation of conflicting rights. Philadelphia: University of Pennsylvania Press, 1990. 534 p.

7. Report by the High Commissioner on National Minorities, Ambassador Kairat Abdrakhmanov. The Organization for Security and Cooperation in Europe. URL: https://www.osce.org/permanent-council/ 503545 (date of request: 20.12.2021). 